\title{
Pensión de viudedad: puntos críticos y vaivenes jurisprudenciales
}

WIDOW'S PENSION: CRITICAL POINTS AND JURISPRUDENTIAL SWINGS

\author{
María Dolores García Valverde \\ Profesora Titular de Derecho del Trabajo y de la Seguridad Social \\ Universidad de Granada \\ mgarciav@ugr.es 100000-0001-8551-7014
}

Recibido: 08.11.2021. Aceptado: 24.11.2021

\begin{abstract}
RESUMEN
En numerosas ocasiones la evolución social precede a la legislativa, en tanto se van presentando nuevas realidades o alternativas que progresivamente van integrándose en la sociedad y, en consecuencia, se han de insertar en el ordenamiento jurídico. Esto está pasando con la pensión de viudedad. Por ello, resulta de gran interés y utilidad analizar cómo se encuentran las nuevas situaciones que sobrepasan la realidad imperante actualmente, como es el caso de los matrimonios polígamos. También se debe estudiar cómo se ha insertado en el ordenamiento jurídico, en lo que respecta a la pensión de viudedad, realidades ya integradas en la sociedad como son el divorcio o las parejas de hecho. Y ver cómo la violencia de género influye en esta materia y los efectos de la unión por el rito gitano. Todo ello desde la perspectiva de los últimos pronunciamientos de los tribunales de justicia.
\end{abstract}

\footnotetext{
ABSTRACT

On many occasions, social evolution precedes legislative evolution, as new realities or alternatives are presented that progressively integrate into society and, consequently, have to be inserted into the legal system. This is happening with the widowhood pension. For this reason, it is of great interest and utility to analyze how new situations are found that exceed the current prevailing reality, as is the case of polygamous marriages. It is also necessary to study how it has been inserted in the legal system, with regard to the widow's pension, realities already integrated in society such as divorce or common-law couples. And see how gender violence influences this matter and the effects of the union through the gypsy rite. All this from the perspective of the latest pronouncements of the courts of justice.
}

\section{PALABRAS CLAVE}

Pensión de viudedad

Poligamia

Parejas de hecho

Matrimonio

\section{KEYWORDS}

Widow's pension

Polygamy

De facto couples

Marriage 


\title{
SUMARIO
}
I. INTRODUCCIÓN
II. LOS SUPUESTOS DE SEPARACIÓN O DIVORCIO Y LA PENSIÓN DE VIUDEDAD
III. LAS PAREJAS DE HECHO Y LA PENSIÓN DE VIUDEDAD
A. Vicisitudes hasta el reconocimiento
B. La necesaria acreditación como pareja de hecho
IV. LA POLIGAMIA Y LA PENSIÓN DE VIUDEDAD
A. Delimitación de la problemática de la poligamia
B. El reconocimiento de la pensión de viudedad a los matrimonios polígamos
V. PENSIÓN DE VIUDEDAD EN EL SUPUESTO DE UNIÓN POR EL RITO GITANO
VI. REFLEXIÓN FINAL
Bibliografía

\begin{abstract}
"Carla se quitó el chal, se pasó los dedos por el largo cabello y se lo soltó. Suspiró profundamente y levantó la cabeza para mirar entre los árboles. Volvió a cubrirse con el chal y miró a Nautaung. Se apoyó en su brazo, dio una palmadita en la rugosa mano y le sonrió con ternura. subieron la escalera de la iglesia. y Nautaung sintió una pena muy honda en el corazón". Tom T. Chamales'
\end{abstract}

\section{INTRODUCCIÓN}

En numerosas ocasiones la evolución social precede a la legislativa, en tanto se van presentando nuevas realidades o alternativas que progresivamente van integrándose en la sociedad y, en consecuencia, se han de insertar en el ordenamiento jurídico mediante un proceso dialéctico en el que la aceptación y rechazo de ese nuevo escenario se contraponen. Dicha premisa, enfocándola en el acceso a la pensión de viudedad, se ve evidenciada en cómo determinadas situaciones alternativas al matrimonio convencional, que antes no tenían ninguna cabida en nuestra sociedad y ordenamiento jurídico, paulatinamente han ido integrándose en el mismo. Ante dicho escenario, resulta de gran interés y utilidad analizar cómo se encuentran las nuevas situaciones que sobrepasan la realidad imperante actualmente, como es el caso de los matrimonios polígamos, también estudiar cómo se ha insertado en el ordenamiento jurídico, en lo que respecta a la pensión de viudedad, realidades ya integradas en la sociedad como son el divorcio o las parejas de hecho. Y ver cómo la violencia de género también afecta a esta materia y los efectos de la unión por el rito gitano. Todo ello desde la perspectiva de los últimos pronunciamientos de los tribunales de justicia.

\section{LOS SUPUESTOS DE SEPARACIÓN O DIVORCIO Y LA PENSIÓN DE VIUDEDAD}

1. Chamales, T. T.: Cuando hierve la sangre, Ediciones Orbis, Barcelona, 1985. 

el derecho a la pensión de viudedad en el caso de separación judicial. En cambio, el reconocimiento en el supuesto de divorcio lo hará su Ley reguladora (Ley 30/1981, de 7 de julio). Ley que también eliminó toda referencia a la culpabilidad o inocencia de los cónyuges al separarse o divorciarse, atribuyéndose expresamente la pensión de viudedad al cónyuge separado y divorciado "con independencia de las causas que hubieran determinado la separación o el divorcio". Desde ese momento se produjo un reconocimiento incondicionado de la pensión de viudedad al cónyuge superviviente de un matrimonio disuelto mediante divorcio, lo que supuso que la única razón de ser de esta pensión en este tipo de situaciones era el mero hecho de estar en un determinado estado civil, dejando de tenerse en cuenta la dependencia económica o estado de necesidad a la hora de determinar si se era beneficiario o no de la pensión de viudedad².

La finalidad de la pensión de viudedad ha ido evolucionando como consecuencia de los cambios sociales producidos, especialmente por la integración de la mujer en el mercado laboral. Así, esta pensión nació con la finalidad de ser una renta sustitutiva que colaborara con el sostenimiento económico de la familia al producirse el fallecimiento del cónyuge, pero se transformó con el transcurso del tiempo hacia una pensión con carácter indemnizatorio por el perjuicio económico causado por la muerte de un miembro de la familia. Así se fue reflejando en la doctrina constitucional ${ }^{3}$. Ello explica que en caso de concurrencia de beneficiarios, la pensión se reparte en función del tiempo de convivencia conyugal y no del estado de necesidad ${ }^{4}$.

Ahora bien, la Ley 40/2007, de 7 de diciembre, de medidas en materia de Seguridad Social, al reformar el régimen jurídico de la pensión de viudedad pretendió recuperar su finalidad como prestación sustitutiva de las rentas perdidas a consecuencia del fallecimiento del causante, cambiando las condiciones de acceso a la pensión para las personas separadas judicialmente, divorciadas o con un matrimonio nulo, vinculando su derecho a acceder a una pensión de viudedad a la pérdida de la pensión compensatoria de los artículos 97 y 98 del Código Civil ${ }^{5}$, y siempre que no hubieran contraído nuevas nupcias o establecido pareja de hecho formal. Conforme a ello, se

2. Consúltese Blasco Rasero, C.: "Aplicación del régimen matrimonial en la delimitación de los beneficiarios de la pensión de viudedad", Temas Laborales, núm. 121, 2013, pp. 63-105.

3. Véase, entre otras, STC 184/1990, de 15 de noviembre; STC 77/2004, de 9 de marzo y STC 174/2004, de 11 de mayo. El Tribunal señala que la pensión de viudedad ahora está vinculada a la de compensación de un daño, que es la minoración de ingresos en los que participaba el cónyuge supérstite, siendo irrelevante que el fallecimiento provoque o no un estado de necesidad, bastando el propio vínculo matrimonial como presupuesto para conceder la pensión.

4. Poquet Catalá, R.: "El acceso de las parejas de hecho a la pensión de viudedad: ¿Una realidad?", Temas Laborales, núm. 119, 2013, pp. 157-188.

5. Repárese que la pensión compensatoria del artículo 97 CC, ya sea pactada o impuesta por el órgano judicial, tiene como finalidad corregir el perjuicio y desequilibrio económico que la ruptura de la relación causa en uno de los cónyuges, que supone un empeoramiento relevante en el nivel de vida de uno de los dos cónyuges respecto al otro, independientemente del estado de necesidad, pues esta pensión ha evolucionado de un prisma asistencial hacia uno más reparador y tendente hacia una potencial igualdad. Si bien un de los elementos más problemáticos de como se ha configurado la vinculación de la pensión de viudedad a la compensatoria es que el pago de esta última puede ser periódico o a través de una prestación única, no pudiendo acceder a la pensión de viudedad en el segundo caso ya que se exige ser acreedor de la pensión hasta el fallecimiento del causante. Una interpretación en Blasco Rasero, C., "Aplicación del régimen matrimonial en la delimitación de los beneficiarios de la pensión de viudedad", ob. cit., pp. 63-105. 
pretendió restringir el reconocimiento de la pensión sólo a aquellos supuestos en que verdaderamente existiera dependencia económica, recuperando de esta manera la pensión, al menos en lo que respecta a los casos de separación, divorcio o nulidad matrimonial, su carácter de renta sustitutoria, es decir, que esté reservada a situaciones en las que la pérdida del causahabiente sí supone un verdadero perjuicio para los supérstites ya que este efectivamente contribuía a su sostenimiento6.

El artículo 220.1 LGSS establece que el acceso a la pensión de viudedad en caso de separación judicial o divorcio está condicionado, además de a que el superviviente no contraiga nuevas nupcias o constituya pareja de hecho, la circunstancia de que este fuera acreedor de la pensión compensatoria del artículo 97 CC ${ }^{7}$ y que esta se extinguiera al fallecer el causante, y por ende, si no se extingue, ya que tal obligación es heredada, o si se extinguió previamente a la muerte del causante -según el artículo 101 CC, tal pensión se extinguirá al desaparecer el desequilibrio económico-, no se considerará beneficiario a este excónyuge ${ }^{8}$.

El principal debate en el caso de reconocer la pensión de viudedad al excónyuge divorciado o separado se centra en la exigencia expresa de que dicha persona debe ser acreedor de la pensión compensatoria. Ello ha abierto un amplio debate, tanto en la doctrina científica como jurisprudencial. Se trata de determinar cómo se debe interpretar el artículo 220 LGSS.

Los Tribunales Superiores de Justicia han ido adoptando criterios contradictorios. Así, el Tribunal Supremo, en un principio, optó por una interpretación literal de la exigencia del precepto de la Ley General de la Seguridad Social. Pero esta doctrina ha sido cambiada por la STS de 29 de enero de 2014, Sala de lo Social, recurso 743/20139. El Tribunal estableció que toda cantidad económica reconocida a favor de un ex cónyuge superviviente que cumpla la función propia de la pensión compensatoria, aunque no sea calificada expresamente como tal, surtirá efectos en este contexto como si de una pensión compensatoria del artículo 97 cc se tratara.

Ahora, el Tribunal Supremo concede la pensión de viudedad siempre que el superviviente percibe alguna cantidad periódica para su exclusivo beneficio, en tanto el fallecimiento del causante pone fin a una obligación asumida por este con la finalidad

6. Comentario en Gala Durán, C.: “Una aproximación a la nueva regulación propuesta en el marco de la pensión de viudedad", IUSLabor, núm. 1, 2007, pp. 1-4.

7. Hay que tener presente que la regla general tiene tres excepciones, en las cuales no se exige al ex cónyuge divorciado o separado ser acreedor de dicha pensión. En primer lugar, el caso de las mujeres separadas o divorciadas, que sin ser acreedoras de la pensión compensatoria, pudieran acreditar haber sido víctimas de violencia de género en el momento de la separación judicial o divorcio, conforme al artículo 220.1 LGSS. En segundo lugar, la disposición transitoria 13ª LGSS establece un régimen transitorio, por el cual, en aquellos supuestos de separación o divorcio previos a la entrada en vigor de la Ley 40/2007 (el 1 de enero de 2008), cuando entre la fecha de separación o divorcio y la muerte del causante no pasaran más de 10 años y el propio vínculo matrimonial haya durado al menos 10 años, además de otra serie de condiciones específicas. En tercer lugar, igualmente se concederá la pensión de viudedad a aquellos que se han separado o divorciado antes del 1 de enero de 2008 cuando el beneficiario tenga 65 años o más, no tenga derecho a otra pensión pública y el matrimonio hubiera durado al menos 15 años, en virtud de la propia disposición transitoria 13a LGSS.

8. Repárese que de la misma forma se manifiesta el artículo 220.3 LGSS en los casos de nulidad matrimonial, vinculando el derecho a la pensión de viudedad al reconocimiento como acreedor de la indemnización compensatoria contenida en el artículo 98 CC.

9. Ponente L. Arastey Sahún. 
de satisfacer el concepto al que atiende la pensión compensatoria, que es buscar la acción reparadora o restablecimiento del equilibrio económico, entendiéndose que la pérdida de esos ingresos acredita la situación de dependencia económica respecto del fallecido, siendo este el presupuesto a tener en cuenta a la hora de considerar si procede otorgar una pensión de viudedad en casos de separación o divorcio ${ }^{10}$.

La doctrina expuesta ha sido reiterada desde el año 2014 así se puede ver en la reciente STS de 3 de diciembre de 2020, n. 1080/202011. El Tribunal considera que, frente a este panorama de pensiones innominadas, no podemos pretender ceñirnos exclusivamente a la denominación dada por las partes. Dicho de otro modo, no cabe una interpretación literal que exija que la pensión compensatoria haya sido fijada con esa denominación para poder admitir que se cumple con el requisito para el acceso a la prestación de viudedad. Por el contrario, habrá que acudir a la verdadera naturaleza de la pensión fijada a cargo del causante, extraída de las circunstancias del caso y acudiendo, en suma, a una interpretación finalista del otorgamiento de aquélla. Por consiguiente, el reconocimiento de la pensión de viudedad pasa en estos casos por determinar si en cada supuesto concreto el fallecimiento pone fin al abono de una obligación asumida por el causante con la finalidad de satisfacer ese concepto a que atiende la pensión compensatoria, excluyendo los excepcionales supuestos en que, en caso de divorcio, se hubieran pactado alimentos en favor del cónyuge supérstite.

Por último, es preciso destacar ciertas particularidades en el caso de que se trate de una mujer víctima de violencia de género ${ }^{12}$. La violencia de género, cuando se ejercita la acción de separación o de divorcio, debe tener efectos personales y patrimoniales que signifiquen la gravedad de la causa originadora de la crisis matrimonial13. Las mujeres víctimas de violencia de género en el momento de la separación judicial o el divorcio (mediante sentencia firme, o archivo de la causa por extinción de la responsabilidad penal por fallecimiento) tendrán derecho a la pensión de viudedad con independencia de ser o no acreedoras de la pensión compensatoria (art. 220.1 LGSS) ${ }^{14}$. Resulta extraño que no mencione también el precepto la nulidad matrimonial15.

Por otro lado, hay que señalar que el agresor condenado por sentencia firme por la comisión de un delito doloso de homicidio pierde la condición de beneficiario de la pensión de viudedad que le corresponda cuando la víctima de dichos delitos es la

10. Allueva Aznar, L. y Ginés i Fabrellas, A.: "La dependencia económica como requisito de acceso a la pensión de viudedad en supuestos de separación o divorcio", Indret: Revista para el Análisis del Derecho, núm. 1, 2015, pp. 1-25.

11. Ponente R. M. Virolés Piñol.

12. Véase el amplio comentario de Gutiérrez Pérez, M.: "La pensión de viudedad frente a las distintas realidades familiares y sociales: poligamia y violencia de género bajo el foco de los últimos pronunciamientos judiciales", Revista Española de Derecho del Trabajo, núm. 210, 2018 (BIB 2018\10432).

13. Afirmación de Vela Sánchez, A. J.: "Violencia de género sobre la pareja y pensión compensatoria", Diario La Ley, núm. 9684, de 29 de julio de 2020.

14. Consúltese la STSJ de Andalucía (Social) de 8 de marzo de 2018 y la STSJ de Cantabria (Social) de 22 de enero de 2009 y Cervilla Garzón, M. J.: El derecho a la pensión de viudedad en el contexto de la violencia de género, Bomarzo, Albacete, 2017, pp. 100 y ss.

15. En este sentido, López Rodríguez, J.: "El derecho a la pensión de viudedad de las víctimas de violencia de género en los supuestos de separación o divorcio", en AA.W.: Protección a la familia y Seguridad Social. Hacia un nuevo modelo de protección sociolaboral (tomo II), Laborum, Murcia, 2018, pp. 259 y ss. También pone de manifiesto otras deficiencias de la regulación. 
causante de la pensión, excepto que haya reconciliación entre ellos (disposición adicional primera de la Ley Orgánica 1/2004, de 28 de diciembre, de Medidas de Protección Integral contra la Violencia de Género) ${ }^{16}$.

Antes de finalizar este apartado dedicado a las situaciones de divorcio, se debe traer a colación una reciente STS, n. 613/2021, de 9 de junio ${ }^{17}$. Considera el Tribunal que la cónyuge supérstite tiene derecho a acrecer su pensión de viudedad si fallece la cónyuge histórica-divorciada, con quien compartía ésta. La sentencia viene a resolver un problema que la norma legal no lo hacía. Es bien sabido que la pensión de viudedad es única, y su cuantía no varía aunque concurran varias beneficiarias con derecho a generarla, la pensión debe dividirse y abonarse en atención al tiempo de convivencia con el causante. Pero la norma no contempla qué ocurre si acaecen incidencias que afectan posteriormente a la cuantía de esta pensión, como el fallecimiento de una de ellas, años después. A esto último es a lo que atiende el Tribunal Supremo declarando que la pensión de viudedad que obtiene la última esposa sí acrece cuando fallece quien fuera la histórica. El principio contributivo es el que justificaría este derecho de acrecimiento ${ }^{18}$.

\section{LAS PAREJAS DE HECHO Y LA PENSIÓN DE VIUDEDAD}

\section{A. Vicisitudes hasta el reconocimiento}

Con la reforma llevada a cabo, en esta materia, por la Ley 40/2007, hay que adaptarse a una nueva realidad social. Así, se amplía la pensión de viudedad a las parejas de hecho, ya que estas se han posicionado como una verdadera alternativa al matrimonio, dado que hay muchas parejas que prefieren convivir sin casarse. Si bien, para acceder a dicha pensión las parejas de hecho, además de cumplir los requisitos propios de los matrimonios, que es tener capacidad para contraerlo, deberán acreditar una convivencia estable y notoria durante al menos los últimos 5 años, a la vez que estar inscritas en registro público o constituidas en documento público con al menos 2 años de antelación, así como dependencia económica del sobreviviente en un porcentaje variable en función de la existencia o no de hijos comunes con derecho a pensión de orfandad. De esta manera se amplía la esfera de protección de la pensión, pero sin que las parejas de hecho alcancen un régimen igual a los matrimonios, destacando además que estas solo tendrán derecho a dicha pensión si el superviviente continúa siendo pareja del fallecido hasta su muerte, situación que no ocurre con los matrimonios al reconocerse la pensión también a los ex cónyuges ${ }^{19}$.

16. Un análisis general en Peña García, M. V: "Las prestaciones específicas de seguridad social para la mujer víctima de violencia de género", en Barrios Baudor, G. L. y Rodríguez Iniesta, G. (dirs.): Derecho Vivo de la Seguridad Social, Laborum, Murcia, 2019, pp. 239 y ss.

17. Ponente A. V. Sempere Navarro.

18. Un comentario de esta sentencia en Ballester Pastor, I.: "La cónyuge supérstite tiene derecho a acrecer su pensión de viudedad si fallece la cónyuge histórica-divorciada, con quien compartía ésta", Revista de Jurisprudencia Laboral, núm. 6, 2021, pp. 1 y ss.

19. Gala Durán, C.: "Una aproximación a la nueva regulación propuesta en el marco de la pensión de viudedad", ob. cit., pp. 1-4. 
Este trato desigual es el que más controversia ha propiciado tras la reforma, ya que una parte de la doctrina científica considera que esta ha significado un punto de partida, pero que se debe avanzar hacia la total equiparación entre matrimonios y parejas de hecho a efectos de acceder a la pensión de viudedad. Y es que a estas se les exige que la condición de pareja de hecho se acredite mediante una serie de formalidades que transforman una realidad meramente social a otra plenamente jurídica, desvirtuándose de esta manera la naturaleza de esta institución ${ }^{20}$. Y además, se exige una determinada dependencia económica del beneficiario respecto al causante, criticándose que no existe ninguna razón que justifique la exigencia de mayores requisitos a las parejas de hecho que a los matrimonios, ya que en tanto se están equiparando ambas situaciones, deberían aplicarse las mismas condiciones para acceder a la pensión ${ }^{21}$.

También la doctrina científica afirma que los requisitos adicionales exigidos a las parejas de hecho para acceder a esta pensión desvirtúan y limitan injustificadamente la aceptación normativa de la realidad social de las uniones de hecho, debido a que la extensión de la pensión a las parejas de hecho debe hacerse en igualdad de condiciones respecto a los matrimonios, pues de lo contrario el Estado está fomentando el matrimonio mediante la pensión de viudedad, no atendiendo así a la finalidad con la que fue creada dicha prestación, y por tanto, la desvirtúa, y genera un efecto disuasorio de la existencia de parejas de hecho, pues se obliga a las personas a casarse para poder obtener la prestación en igualdad de condiciones, atentando contra la libertad del individuo de establecer otros modos de convivencia alternativos al matrimonio, en virtud del libre desarrollo de la personalidad configurado en el artículo 10 CE22.

De esta manera, se considera cuestionable que en tanto se regula un modelo familiar diferente, entre opciones legítimas, se puedan atribuir derechos disminuidos sin atentar contra la plena igualdad entre ellos, ya que con esta regulación se pretende primar el matrimonio sobre otras alternativas de familia, no estando justificado.

Sin duda se está ante una materia muy discutida entre la doctrina científica. Se sigue discutiendo si la regulación dada a la pareja de hecho desvirtúa a la misma. Ante lo que una parte de la doctrina considera que no es así, puesto que aunque al configurar el supuesto de hecho se diseña un modelo legal de pareja de derecho, y no de hecho, estableciendo dos modelos convivenciales: el formalizado y el no formalizado, ello es inevitable ya que de alguna manera se ha de poder acreditar la existencia de

20. Consúltese De Castro Mejuto, L. F.: "A propósito de la pensión de viudedad para las parejas de hecho", Anuario da Faculta de Dereito da Universida de A Coruña, núm. 12, 2008, pp. 239-246.

21. Ballester Pastor ("La cuantía de la pensión de viudedad tras la Ley 40/2007, de 4 de diciembre: cambios puntuales y entrada en juego de las uniones de hecho", Tribuna Social, núm. 209, 2008, p. 69) considera que el requisito económico de la dependencia económica del beneficiario respecto del fallecido ha de ser la regla general aplicable a todas las pensiones de viudedad, sea un matrimonio o una pareja de hecho, reconfigurando la pensión con un fin sustitutorio de rentas, como las demás pensiones de Seguridad Social, en vez de indemnizar un mero daño moral o afectivo. Si bien, considera que en tanto no sea igual para parejas de hecho y matrimonios, supone un trato desigual injustificado para las primeras respecto de las segundas.

22. Así lo ha manifestado Martínez Abascal, V. A.: "Las parejas de hecho y la pensión de viudedad en la Ley 40/2007, de 4 de diciembre: ¿una equiparación inviable?", Aranzadi Social, vol. 2, núm. 17, 2010, pp. 59-90. 
una pareja de hecho, teniendo una difícil articulación el carácter esencialmente fáctico de una realidad afectiva y convivencial con la necesaria formalización de esa realidad, delimitando el supuesto, pues no resulta fácil insertar en el ámbito jurídico aquello que es esencialmente fáctico sin desvirtuar dicha facticidad. Precisamente, para respetar su naturaleza, se ha de identificar la voluntad de permanencia y estabilidad de la convivencia more uxorio, no siendo esto presumible, sino que ha de constatarse por el transcurso del tiempo. Por lo que la existencia de una pareja de hecho no ha de depender de un acto jurídico constitutivo, como ocurre con el matrimonio, ya que esto suprimiría su elemento esencial que es la facticidad, sino que ha de consolidarse a través del transcurso de un tiempo de convivencia afectiva, que ha de poder acreditarse mediante alguna exigencia formal, a través de cualquier medio de prueba válido en Derecho, como es la inscripción en un registro de uniones de hecho ${ }^{23}$.

Junto a este intento de la doctrina científica por aclarar sí hay discriminación o no a las parejas de hecho, la jurisprudencia afirma que no hay discriminación por el hecho de regular con distintos parámetros a unos y otros, y considera que establecer determinados requisitos a las parejas de hecho se fundamenta en que aquellos que eligen libremente no asumir los deberes conyugales, no tienen el mismo derecho a la protección social pública en caso de que fallezca su pareja frente a quienes han contraído matrimonio constituyendo una agrupación familiar reforzada para la atención de las necesidades económicas de sus miembros. Además, argumenta que la protección jurídica de la familia se debilita cuando resulta más desventajoso para los ciudadanos contraer matrimonio que convivir more uxorio, siendo esto último legítimo, pero más favorable para conservar las opciones del individuo que para la efectividad de las responsabilidades familiares y del interés de la familia. El tribunal parte de la idea de que quienes no quieren asumir obligaciones entre ellos provocan que la sociedad las tenga con ellos 24 .

También resulta esclarecedora, a estos efectos, la Exposición de Motivos de la Ley 40/2007, que estableció que se pretendía "adecuar la acción protectora del sistema a las nuevas realidades sociales y así reconocer la pensión de viudedad a las parejas de hecho que acrediten convivencia mutua, estable y notoria" y "una aproximación, en la medida de lo posible, a la institución matrimonial". Sin embargo, se añade: "No obstante, habida cuenta de la imposibilidad de conseguir la plena equiparación entre las parejas matrimoniales y las de hecho, se hace inviable la plena igualación en el régimen jurídico de las prestaciones de viudedad". Por lo que el legislador parte de la premisa de que estos dos regímenes jurídicos no son equiparables jurídicamente, apoyándose en la doctrina consolidada del Tribunal Constitucional que afirma que el matrimonio y la convivencia extramatrimonial no son realidades equivalentes, ya que el primero es una institución social garantizada constitucionalmente, a diferencia de

23. Moliner Navarro, R.: "El derecho a la percepción de una pensión de viudedad para las uniones de hecho formalizadas en la Comunitat Valenciana después de la STC 110/2016, de 9 de junio", Derecho Civil Valenciano, núm. $20,2016$.

24. Véase el comentario en De Castro Mejuto, L. F.: "A propósito de la pensión de viudedad para las parejas de hecho", ob. cit., pp. 239-246. 
la unión de hecho more uxorio, y por tanto, el legislador, en su margen de configuración normativa, establece libremente que las parejas de hecho podrán acceder a la pensión de viudedad en tanto acrediten una serie de requisitos adicionales ${ }^{25}$.

Para el Tribunal Constitucional los requisitos adicionales exigidos a las parejas de hecho respecto a los matrimonios no suponen un trato discriminatorio hacia éstas ${ }^{26}$. El Tribunal se basa en que no toda desigualdad de trato legislativo en la regulación de una materia supone una vulneración del derecho fundamental a la igualdad del artículo 14 CE, ya que en este caso las situaciones no pueden considerarse sustancialmente iguales y dicho trato desigual está justificado de manera objetiva y razonable. Además, no hay discriminación por el hecho de que las parejas de hecho que cumplen los requisitos accedan a la pensión de viudedad en detrimento de aquellas que no los cumplen, ya que la ley solo considera pareja de hecho a las primeras. Por tanto, el Tribunal Constitucional considera que la exigencia de la constitución formal de la pareja de hecho con una antelación mínima a la fecha del fallecimiento del causante no vulnera el derecho a la igualdad, siendo un mero medio para constatar la convivencia entre los miembros de una pareja de hecho, a partir de la cual se podrá identificar que existe una situación de necesidad merecedora de protección a través de la pensión de viudedad. Y por tanto, solo las parejas de hecho inscritas pueden acceder a esta pensión.

Además, el Tribunal afirma que los requisitos establecidos en el artículo 222.1 LGSS son acumulativos y simultáneos. Por lo que, para que los miembros de una pareja de hecho puedan acceder a esta pensión, independientemente de que se haya desarrollado una auténtica convivencia afectiva y estable, no deben estar impedidos para contraer matrimonio conforme al Código Civil (requisito subjetivo), deben demostrar la convivencia de 5 años (requisito objetivo) y acreditar la pareja de hecho mediante la inscripción en registro o la formalización en documento público (requisito formal). De esta manera, el mencionado artículo atiende a dos realidades: la convivencia afectiva y estable consolidada por el transcurso del tiempo; y la acreditación de la misma a través de determinados medios que el derecho considera válidos para asegurar un determinado nivel de seguridad jurídica ${ }^{27}$.

Por tanto, según el Tribunal Constitucional, la acreditación de la pareja de hecho válidamente constituida durante al menos 2 años de antelación es un requisito formal (ad solemnitatem) independiente del hecho fáctico de la cohabitación, exigida como requisito material durante cinco años anteriores a la fecha del hecho causante, considerando de esta manera que no se trata de un requisito que puede ser cumplido de dos maneras diferentes, sino de dos exigencias distintas: la material que sirve para demostrar la convivencia por un periodo mínimo y la formal que acredita la constitución de la pareja ante derecho con cierta antelación ${ }^{28}$.

\footnotetext{
25. Así, Chano Regaña, L.: "El derecho a pensión de viudedad del supérstite de una unión de hecho homosexual", Anuario de la Facultad de Derecho de la Universidad de Extremadura, núm. 31, 2014, pp. 125-137.

26. En este sentido, SSTC 44/2014, 45/2014 y 51/2014, de 7 de abril. Y también la STC 60/2014, de 5 mayo.

27. Ureña Martínez, M.: "Parejas de hecho y pensión de viudedad tras las últimas sentencias del tribunal constitucional", Derecho Privado y Constitución, núm. 29, 2015, pp. 347-388.

28. Chano Regaña, L.: "El derecho a pensión de viudedad del supérstite de una unión de hecho homosexual", ob.
} 
La doctrina mantenida por el Tribunal Constitucional también es defendida por parte de la doctrina científica, pues defiende la existencia de ambos periodos de tiempo basándose en que persiguen fines diferentes, en tanto el certificado de empadronamiento acredita una convivencia en común de dos personas en un mismo domicilio, pero no la relación de afectividad análoga a la conyugal, la cual sí queda probada con la inscripción en el registro o documento público ${ }^{29}$.

Sin embargo, otra parte de la doctrina acepta la idea de exigir una serie de requisitos para acceder a la pensión, pero no en los términos configurados actualmente, pues consideran que tales requisitos deberían ser alternativos y no acumulativos con el fin de evitar injusticias, pues debería pretenderse que tales exigencias sirvieran para acreditar la realidad convivencial, que es el fin último que se pretende y aquello que justifica la protección de la pensión. Pues no se trata de otorgar una prestación económica al que acredita una determinada situación jurídica, sino asistir económicamente al que necesita de esa prestación por el fallecimiento de la persona con la que convivía, debido a la dependencia económica, si existe, o la situación de necesidad surgida. Y en virtud de lo anterior, también afirma que se debería exigir la acreditación de la situación de convivencia y de dependencia o necesidad tanto a las parejas de hecho como al matrimonio para que la pensión de viudedad atendiera a su verdadero fin ${ }^{30}$.

Tras la entrada en vigor de la Ley 40/2007, que reformó varios aspectos de la pensión de viudedad, se plateó ante el Tribunal Constitucional varios recursos de inconstitucionalidad. En el momento actual no son de tanto interés, pero si deben ser tenidos presentes para entender el discurso general y avances de la doctrina fijada por el Alto Tribunal ${ }^{31}$. Recientemente, se ha dictado el ATC n. 8/2019, de 12 de febrero, que

cit., pp. 125-137.

29. Desdentado Daroca, E.: La pensión de viudedad ante los nuevos retos del Derecho de familia, Bomarzo, Albacete, 2009, p. 125.

30. Moliner Navarro, R.: "El derecho a la percepción de una pensión de viudedad para las uniones de hecho formalizadas en la Comunitat Valenciana después de la STC 110/2016, de 9 de junio", ob. cit.

31. Hay que traer a colación la disposición adicional $3^{a}$ de la Ley 40/2007, la cual establecía un régimen transitorio y excepcional por el que se reconocía, pese a no cumplir los requisitos generales establecidos por la norma, la pensión de viudedad a las parejas de hecho cuando se produjere la muerte del cónyuge antes del 1 de enero de 2008 (fecha en entrada en vigor de dicha ley) y acontecieren una serie de circunstancias acumulativas, entre las cuales, se encontraba en el apartado c) de esta disposición la exigencia de que el causante y el beneficiario debían tener, al menos, un hijo en común para acceder a esta pensión en este supuesto excepcional. Ante esto, la STC 41/2013, y posteriormente la STC 55/2013, se pronunciaron sobre dicho requisito, declarándolo inconstitucional por vulnerar la cláusula general de igualdad, dado que este resultaba imposible de cumplir para las parejas de hecho heterosexuales infértiles y homosexuales (en tanto, la adopción es un proceso complejo y demorado en el tiempo), entendiendo el Tribunal que no era justificable bajo el argumento de que resultaba necesario para acreditar de forma inequívoca una efectiva y estable convivencia more uxorio entre el causante y el beneficiario, y por tanto, se declaró la nulidad de dicho requisito. Además, la disposición adicional 15ª de la Ley 51/2007, de 26 de diciembre, que recogía la misma fórmula retroactiva excepcional para la pensión de viudedad de las parejas de hecho en el Régimen de Clases Pasivas, fue posteriormente derogada respecto a dicho precepto por la STC 81/2016, la cual aplicó analógicamente la solución dada en la STC 41/2013 al darse identidad de fundamento y regulación en las dos disposiciones legales cuestionadas.

Por otro lado, la reforma de 2007 introdujo en el antiguo artículo 174.3.5 LGSS una remisión a la legislación específica de ciertas Comunidades Autónomas, pues afirmaba que la consideración y acreditación como pareja de hecho atendería a lo establecido en la legislación específica de aquellas que disponen de Derecho civil propio, mientras que 
inadmite por notoriamente infundada la cuestión de inconstitucionalidad promovida por el Juzgado de lo Social núm. 3 de Barcelona respecto del artículo 174.3, párrafos primero, segundo y tercero, de la Ley General de la Seguridad Social, texto refundido de 1994 (aprobado por Real Decreto Legislativo 1/1994, de 20 de junio) (LGSS), en la redacción dada por la Ley 40/2007, de 4 de diciembre, de medidas en materia de Seguridad Social. El supuesto de hecho trata del fallecimiento de un señor que es pareja de una mujer que percibe una pensión por incapacidad permanente absoluta. Se debe determinar si hay dependencia económica como exige el artículo 221.1 LGSS. La pensión por incapacidad permanente absoluta está exenta según la Ley del Impuesto sobre la Renta de las Personas Físicas.

Concluye el Tribunal que no es inconstitucional la decisión del legislador de condicionar el derecho a las pensiones de viudedad de las personas sobrevivientes de las parejas de hecho a su situación real de necesidad económica32.

\section{B. La necesaria acreditación como pareja de hecho}

Para ser considerado pareja de hecho legalmente en lo que respecta al acceso a la pensión de viudedad se ha de atender exclusivamente a la legislación estatal relativa a la Seguridad Social, y en concreto al artículo 221.1 LGSS, debiendo cumplirse simultáneamente los requisitos enunciados en el mismo. Partiendo de esa premisa, ahora debemos profundizar cómo se pueden cumplir tales requisitos, pues la respuesta dependerá de cómo sea interpretado el artículo que los contiene.

El primer requisito, relativo a la capacidad matrimonial, que es el único compartido con los matrimonios, no tiene discusión alguna, pues se trata de cumplir las exigencias contenidas en el Código Civil para poder casarse. Por contra, los siguientes dos requisitos, se exigen para acreditar la existencia de pareja de hecho y sí han sido objeto de debate y contradicción.

Por un lado, está el requisito objetivo, según el cual, la acreditación de un período de convivencia estable, notoria e ininterrumpida durante al menos los últimos 5 años por parte de la pareja de hecho para ser considerada como tal se ha de documentar, conforme a una interpretación literal de dicho precepto, mediante el certificado de empadronamiento.

De esta manera lo consideraba el Instituto Nacional de la Seguridad Social, que entendía este certificado como un requisito constitutivo del derecho a la pensión de

en el resto de Comunidades se aplicaría el régimen general establecido en la LGSS (antiguo art. 174.3.4º). Ante esta situación y dado que cada Comunidad había exigido distintas circunstancias para la consideración y acreditación de la pareja de hecho, los requisitos que determinaban el acceso a la pensión de viudedad variaban en función de la residencia o vecindad civil de las personas, lo cual suponía un tratamiento desigual sin justificación objetiva alguna en función del territorio en el que se resida y que además no respeta una competencia básica del Estado, como es la de fijar los requisitos y el régimen de Seguridad Social de forma uniforme para todo el territorio nacional, vulnerando así los artículos 14 y 149.1.17 CE. A consecuencia de tal hecho, este artículo fue declarado nulo por la STC 40/2014.

32. Véase el comentario de Casas Baamonde, M. E.: "La pensión de viudedad de las parejas de hecho y su legítima vinculación asistencial a situaciones de necesidad económica", Revista de Jurisprudencia Laboral, núm. 1, 2019, disponible en https://www.boe.es/biblioteca_juridica/anuarios_derecho/abrir_pdf.php?id=ANU-L-2019-00000000322. 
viudedad, sin que pueda ser sustituido por otros medios de prueba, amparándose además en determinadas sentencias que así lo indicaban como eran las sentencias del Tribunal Superior de Justicia de Madrid, de 17 de abril, 29 de septiembre y 30 de octubre de 2009. En la misma línea había sentencias de los Tribunales Superiores de Justicia de Cantabria, Asturias y Navarra que consideraban que el precepto del artículo 221.2 LGSS no admitía interpretaciones extensivas, no estando ante un supuesto de prueba libre, puesto que, si así lo fuera, así lo hubiera reflejado el legislador, por lo que se configura como un supuesto de prueba tasada ${ }^{33}$.

También parte de la doctrina científica defendía su interpretación literal, afirmando que: "con independencia de su acierto y al margen de razones de oportunidad, este criterio es el que debe mantenerse considerando el certificado de empadronamiento como requisito constitutivo, al ser, en principio, ésta la forma como lo ha configurado el legislador ante la dificultad de acreditar la duración de la convivencia en las parejas de hecho, y como medida que evita el fraude"34.

Sin embargo, otros tribunales consideraban que el certificado no debía ser la única prueba para demostrar la convivencia de la pareja de hecho ya que este no constata fehacientemente que la convivencia sea estable o notoria, pues, ya sea por inactividad del sujeto o con un fin fraudulento, este puede estar empadronado en un lugar y residir en otro ${ }^{35}$. En consecuencia, no se puede dar valor ad solemnitatem a dicho certificado y actuar como presunción iuris et de iure de la convivencia de la pareja ya que esto serviría para amparar situaciones fraudulentas con imposibilidad de destruirlas mediante prueba en contrario ${ }^{36}$. Por ello, la STSJ de Castilla-La Mancha, de 9 de julio de 2009 considera que este certificado ha de tener presunción iuris tantum y servir como medio ordinario de acreditación de la convivencia, compatible con otros medios probatorios, como es el caso de informes policiales, testificales y otros documentos valorables por el juez cuando así estime conveniente ${ }^{37}$.

El Tribunal Supremo, en su sentencia de 25 de mayo de 2010, vino a sentar doctrina, que fue reiterada en posteriores sentencias, unificando doctrina, al determinar que el empadronamiento municipal no es un medio de prueba exclusivo, contrario a la posición estricta del Instituto Nacional de la Seguridad Social, pues considera al certificado como un medio probatorio más, entre otros posibles, ya que lo importante es demostrar la existencia real de la pareja de hecho, y no tanto la forma de su

33. Poquet Catalá, R.: "El acceso de las parejas de hecho a la pensión de viudedad: ¿Una realidad?”, ob. cit., pp. 157-188.

34. Molins García-Atance, J.: "La pensión de viudedad tras la Ley 40/2007, de medidas en materia de Seguridad Social", Aranzadi Social, vol. 1, núm. 6, 2008, p. 107.

35. Véase STSJ de Baleares, de 30 de abril de 2009.

36. STS Navarra de 28 de julio de 2009. Y resultando perjudicial para la propia Seguridad Social (STS de Castilla y León de 22 de abril de 2009).

37. En la misma línea, han sido admitidos como medios de prueba un contrato de compraventa de la vivienda que constituyó el domicilio conyugal en la STSJ de Baleares de 18 de febrero de 2010 una cartilla bancaria conjunta en la que se domiciliaban los recibos de gastos comunes de la vivienda familiar en la STS de Madrid de 30 de septiembre de 2009; y un certificado del Ayuntamiento, basado en la información de la Policía Local, que acreditaba el domicilio real en la STSJ de Castilla-La Mancha de 9 de julio de 2009. 
acreditación, como ya habían indicado anteriormente la STSJ de Castilla y León, de 10 de junio de 2010 y la STSJ de Cataluña, de 10 de junio de 2009, por lo que podrá llevarse a cabo por cualquier medio de prueba admitido en Derecho, en especial si se trata de un documento público, lo cual también es apoyado por las SSTSJ de Cataluña de 14 de febrero de 2011, de Madrid de 19 de julio de 2010 y de Extremadura de 5 de octubre de 2010. Por tanto, el Tribunal Supremo apuesta por una interpretación flexible, según la cual se puede acreditar la convivencia mediante otras pruebas alternativas en tanto sean lo suficientemente fehacientes, y rechazando pruebas menos convincentes como la prueba testifical o el documento privado ${ }^{38}$.

Por lo que se refiere al requisito formal, también se ha cuestionado si solo era posible acreditar la existencia de la pareja de hecho mediante la inscripción registral o constitución en documento público de la misma con la antelación establecida (interpretación literal de la norma) o si era posible usar otros medios alternativos de prueba que lo acreditasen (interpretación flexible).

Ante esto, parte de la jurisprudencia consideraba que el elemento constitutivo del derecho a esta pensión era la existencia real de la pareja y no la forma de acreditarla (STS de 25 de mayo de 2010 y SSTSJ Castilla y León de 19 de enero y 18 de febrero de 2010), por lo que la inscripción oficial tiene un simple valor ad probationem, pudiendo probarse la realidad de la unión de hecho a través de otros medios no previstos por el legislador, como podrían ser la existencia de hijos comunes o la firma ante notario de un contrato de compraventa de la vivienda familiar (SSTSJ de Baleares, de 18 de febrero de 2010 y de 3 de marzo de 2010) o la tenencia de una cartilla de la Seguridad Social donde aparece la viuda incluida a los efectos de asistencia sanitaria (STSI de Andalucía, de 13 de abril de 2011). Sin embargo, en la actualidad el Tribunal Supremo estima que la existencia de la pareja de hecho solo puede acreditarse mediante la inscripción registral o constitución ante documento público, no pudiendo ser sustituido por otros medios de prueba, indicando expresamente que el libro de familia no sirve como prueba de la constitución de la pareja, ya que no fue así previsto por el legislador y que solo sirve para acreditar la afiliación, como indican las SSTS de 3 de mayo y de 15 de junio de 2011.

Hay que traer a la palestra la reciente STS de la Sala de lo Social, n. 350/2019, de 9 de mayo ${ }^{39}$. La cuestión material debatida es la validez de un acta notarial de manifestaciones como documento público para la válida constitución de la pareja de hecho con efectos jurídicos para el acceso a la pensión de viudedad. El Tribunal no admite el recurso de casación para la unificación de doctrina, por falta de contradicción. Ello lleva a afirmar que desde el punto de vista material o sustantivo seguimos sin doctrina unificada en relación a la virtualidad constitutiva de las actas notariales de manifestaciones a los efectos del artículo 221.2 LGSS. Con todo, su indudable carácter de "documento público" no debería ser un impedimento para convertirse en vehículo válido

38. Poquet Catalá, R., "El acceso de las parejas de hecho a la pensión de viudedad: ¿Una realidad?", ob. cit., pp. 157-188.

39. Ponente M. Calvo Ibarlucea. 
para la declaración de la voluntad constitutiva de la pareja "de derecho" que permite el acceso a la pensión de viudedad ${ }^{40}$.

Entre los últimos pronunciamientos destaca la STS de 7 de abril de 2021, n. 480/2021, Sala de lo Contencioso-Administrativo ${ }^{41}$. Concede la pensión de viudedad a un ama de casa tras el fallecimiento de su pareja, un guardia civil (adscrito al régimen de clases pasivas) con el que convivió durante treinta años y con el que tuvo tres hijos. Le concede la pensión de viudedad, aunque nunca se casaron, ni se inscribieron como pareja de hecho en los registros de las Comunidades Autónomas ni de los Ayuntamientos, ni en un documento público. Por lo tanto, corrige lo establecido en la normativa de Clases Pasivas del Estado y de Seguridad Social.

Esta sentencia del alto Tribunal dispone que la prueba de la existencia de una pareja de hecho no solo puede acreditarse a los efectos del reconocimiento de la pensión de viudedad mediante los medios señalados en el párrafo cuarto del artículo 384 de la Ley de Clases Pasivas, si no también mediante certificado de empadronamiento o cualquier otro medio de prueba válido en derecho que demuestre la convivencia de manera inequívoca.

Por último, es preciso traer a colación la STS de 14 de octubre de 2020, Sala de lo Social, recurso n. 2753/2018 ${ }^{42}$. Concede la pensión de viudedad de parejas de hecho, siempre que cumpla los restantes requisitos legalmente exigidos, a la mujer que, por razón de violencia de género, no estaba ya unida ni convivía con la pareja en el momento del fallecimiento de ésta. El Tribunal realiza una interpretación con perspectiva de género a la hora de interpretar el artículo 221 LGSS. Así, la ausencia de convivencia no puede ser un obstáculo infranqueable para que la mujer víctima de violencia pueda acceder a la pensión de viudedad de parejas de hecho.

\section{LA POLIGAMIA Y LA PENSIÓN DE VIUDEDAD}

\section{A. Delimitación de la problemática de la poligamia}

En la sociedad actual existe un fuerte flujo migratorio que trae consigo una importante diversidad cultural, que en ocasiones puede dar lugar a ciertos conflictos en el plano jurídico, como ocurre con especial énfasis en el ámbito de las relaciones conyugales, ya que puede darse la situación de que el ordenamiento jurídico de un país extranjero admita un tipo de matrimonio que resulte contrario con el derecho interno español43.

En España el matrimonio es de carácter formal, y por ende, la validez del mismo viene condicionada a que su celebración sea conforme al procedimiento establecido,

40. Un comentario en Vicente Palacio, M. A.: "Pensión de viudedad y el tipo de documento público válido para constituir la pareja de hecho", Revista de Jurisprudencia Laboral, núm. 4, 2019, pp. 1-7.

41. Ponente C. Pico Lorenzo.

42. Ponente I. García-Perrote Escartín.

43. Véase García Valverde, M. D.: "Mujeres musulmanas en España. Poligamia y derecho a la pensión de viudedad", en Carballeira Debasa, A. M. y González Santos, M. T. (coords.): Islam: pasado, presente y futuro. ¿Hacia una sociedad intercultural?, Dykinson, Madrid, 2016, pp. 129-146. 
admitiendo los artículos 51 a 59 CC tanto el matrimonio civil como el celebrado en la forma prevista por una confesión religiosa inscrita, teniendo España, en virtud de esto último, firmados acuerdos por lo que se otorga validez al matrimonio celebrado en territorio español conforme a las normas y ritos de otras confesiones religiosas, además de la católica, como son la evangélica, la judía y la musulmana, mediante las Leyes 24/1992, 25/1992 y 26/1992, todas del 10 de noviembre, respectivamente. Además estos matrimonios han de ser inscritos en el Registro Civil para el pleno reconocimiento de los efectos civiles ${ }^{44}$.

La STC 194/2014, de 1 de diciembre, denegó la pensión de viudedad al cónyuge superviviente de un matrimonio contraído por el rito islámico sin haberse tramitado el previo certificado de capacidad matrimonial ni inscribirse en el Registro Civil al considerar que dicho vínculo matrimonial no es válido al no cumplir uno de los requisitos establecidos en la Ley 26/1992 del Acuerdo de Cooperación entre España y la Comisión Islámica española, como es la obtención del mencionado certificado, cuya función es demostrar la capacidad nupcial de los contrayentes ante el encargado del Registro Civil, es decir, con el mismo se pretende verificar que estos cumplen los requisitos de fondo para la validez del matrimonio, por lo que sin el mismo tal matrimonio no existe. Si bien, es posible contraer matrimonio sin dicho expediente, pero resultará imprescindible la inscripción del matrimonio en el Registro Civil para otorgar validez al mismo, pues de esta manera se comprueba que se cumplen los requisitos de capacidad del Código Civil para contraer matrimonio ${ }^{45}$.

Distinto es el supuesto de la poligamia. Está permitida en la Ley islámica, conocida como la Sharia, en la que el derecho, la tradición y la religión están estrechamente unidos, y en la Mudawana, que es el Código de Familia de Marruecos. Conforme a esta, el varón puede contraer matrimonio simultáneo con hasta 4 esposas, siempre y cuando acredite que se dan causas objetivas y de carácter excepcional que justifiquen el nuevo matrimonio y disponga de recursos financieros suficientes para sostener a toda la familia, a la vez que obtenga el consentimiento de la primera esposa, pudiendo esta divorciarse con derecho a ser resarcida en caso de no estar de acuerdo o incluir una cláusula en el pacto matrimonial que prohíba la poligamia46.

Pero nuestro Derecho Civil y Penal prohíbe celebrar en territorio nacional el matrimonio polígamo, ya que el artículo 46.2 CC no permite expresamente que aquella persona que ya está ligada a otra conyugalmente celebre un nuevo matrimonio y el artículo 73.2 CC otorga la nulidad del mismo a quienes infrinjan dicha prohibición. Además, el artículo 217 del Código Penal -en adelante, CP- lo tipifica como delito so pena de prisión. Por su parte, la normativa sobre extranjería asume una postura un

44. Sobre esta cuestión existe jurisprudencia (aunque no de forma unánime), como fueron la STC 199/2005, de 15 de noviembre, y la STS de 15 de diciembre de 2004, que le reconocen determinados efectos en el ámbito socio-laboral, pues otorgan la pensión de viudedad a la esposa supérstite de este tipo de matrimonios no inscritos.

45. Blázquez Rodríguez, I.: "Matrimonio celebrado por el rito islámico. Certificado de capacidad matrimonial y derecho internacional privado", Cuadernos de Derecho Transnacional, vol. 7, núm. 2, 2015, pp. 382-399.

46. Saad Bentaouet, M.: "El convenio bilateral hispano-marroquí de seguridad social y su aplicación", e-Revista Internacional de la Protección Social, vol. III, núm. 2, 2018, pp. 91-107. 
tanto ambigua, ya que el artículo 17.1.a) de la Ley Orgánica 4/2000, de 11 de enero, sobre derechos y libertades de los extranjeros en España y su integración social, regula el reagrupamiento familiar, estableciendo que no podrá reagruparse más de un cónyuge, incluso aunque la ley personal del extranjero admita esa posibilidad matrimonial, dando a elegir a cuál esposa desea reagrupar.

Por otro lado, existe una norma de conflicto, contenida en el artículo 9.1 CC, que remite a la ley nacional del contrayente a la hora de considerar válido el matrimonio contraído por extranjeros fuera de España, es decir, se considerará válido en España el matrimonio constituido en el extranjero conforme a la ley nacional del contrayente. Además, en el acuerdo hispano marroquí (art. 7 de la Ley 26/1992) se reconoce efectos civiles al matrimonio celebrado según la forma religiosa establecida en la Ley islámica, incluyendo así el polígamo.

Ante dicha premisa, el matrimonio polígamo contraído en un país y por los nacionales de dicho país en el que sea legal debería ser considerado válido en España. Sin embargo, la regla general, que sería la aplicación de la norma de conflicto, se ve restringida en tanto remite a una ley extranjera que colisiona con el orden público internacional español, contenido en el artículo 12.3 CC ${ }^{47}$.

De esta manera, hay numerosas resoluciones de la Dirección General de los Registros y del Notariado -DGRN en adelante- (de 11 de mayo de 1994, de 8 de marzo de 1995, de 3 de diciembre de 1996, de 14 de mayo de 2001 y de 30 de septiembre de 2008), denegando la inscripción en el Registro Civil de los matrimonios polígamos contraídos legalmente en el extranjero, al considerar inaplicable excepcionalmente las normas que admiten la poligamia al colisionar con el orden público internacional español, al que se refiere el artículo 12.3 CC, argumentando que esta figura atenta contra la dignidad constitucional de la mujer y contra la concepción monógama del matrimonio en España y, en definitiva, causa un perjuicio para la sociedad española.

Mientras que la legislación civil, penal y específica sobre extranjería rechaza toda unión matrimonial que no sea monógama, existen dos convenios internacionales suscritos por España que atribuyen a las uniones matrimoniales polígamas de los nacionales de los países firmantes el derecho de acceder a la pensión de viudedad del sistema de Seguridad Social. El artículo 23 del Convenio Hispano-Marroquí sobre Seguridad Social, firmado el 8 de noviembre de 1979 y publicado en el BOE de 5 de julio de 198248, afirma que "la pensión de viudedad causada por un trabajador marroquí será distribuida en su caso, por partes iguales y definitivamente entre quienes resulten ser, conforme a la legislación marroquí, beneficiarias de dicha prestación". Con parecidos términos se pronuncia el Convenio Hispano-Tunecino, firmado el 26 de febrero de 2001, publicado en el BOE de 26 de diciembre de 2001 y en vigor desde el 1 de enero de 2002. Así, estos convenios reconocen la pensión de viudedad a las

\footnotetext{
47. Asín Cabrera, M. A.: "La práctica judicial española ante la diversidad multicultural de las relaciones familiares", Anuario de la Inmigración en España 2014, 2015, pp. 302-326.

48. Modificado por el Protocolo Adicional al Convenio de 27 de enero de 1998.
} 
esposas del marido polígamo fallecido. Aunque, en todo caso, la pensión es única y deberá repartirse por partes iguales entre las esposas.

De lo anterior se concluye que dichos convenios reconocen determinados efectos en materia socio-laboral a una figura que está prohibida en la legislación civil y penal de producción interna y que colisiona con determinados principios y valores constitucionales de los artículos 10 y 14 CE.

\section{B. El reconocimiento de la pensión de viudedad a los matrimonios polígamos}

En virtud de la propia legislación española, resulta evidente que el matrimonio polígamo, ya sea contraído por españoles o extranjeros, en España o en el extranjero, no es considerado válido en territorio español, y por ende, no despliega todos sus efectos civiles. Sin embargo, que el matrimonio polígamo sea inválido en España no excluye necesariamente la posibilidad de que pueda desplegar determinados efectos, especialmente en el ámbito socio-laboral, en lo relativo al reconocimiento de la pensión de viudedad ${ }^{49}$.

En este sentido, existen numerosas sentencias de nuestros tribunales que han denegado la pensión de viudedad a las esposas supervivientes de un varón polígamo ${ }^{50}$. Estas resoluciones consideraron que la pensión de viudedad, en caso de poligamia, corresponde exclusivamente a la primera esposa del varón, ya que sería el único matrimonio reconocido conforme al Derecho español, siendo nulo de pleno derecho los ulteriores matrimonios producidos en tanto no se disolvió el primero y, por ello, no se les reconoce efectos jurídicos algunos ${ }^{51}$.

Frente a esta doctrina judicial, existen otros pronunciamientos que reconocen efectos en materia de protección social a la poligamia ${ }^{52}$. Dentro de las sentencias que reconocen la pensión de viudedad a las esposas de un polígamo, se distingue también entre las que aplican el criterio de reparto establecido en los Convenios de España con Marruecos y Túnez, distribuyendo la pensión a partes iguales entre las beneficiarias ${ }^{53}$, y las que rechazan el criterio mencionado y aplican por analogía el antiguo artículo 174.2 LGSS, y por tanto, reparten la pensión entre los beneficiarios

49. García Valverde, M. D.: "Mujer musulmana en España. Especial consideración del derecho a la pensión de viudedad", Revista Española del Derecho del Trabajo, núm. 181, 2015, pp. 69-98.

50. Entre otras, SSTSJ de Cataluña de 30 de julio de 2003; de 25 de abril de 2016 y de 27 septiembre de 2017 (eran matrimonios polígamos contraídos en Gambia y Senegal) y de la Sala de lo Social del TSJ de la Comunidad Valenciana de 6 junio de 2005 (segundo matrimonio contraído en México).

51. Valverde Martínez, M. J. y Carrascosa González, J.: "Poligamia en Marruecos y pensión de viudedad en España. El Tribunal Supremo y el orden público internacional atenuado", Cuadernos de Derecho Transnacional, vol. 10, núm. 2, 2018, pp. 718-731.

52. STS de Andalucía (Málaga) de 18 de junio de 2015. Concedió la pensión de viudedad a los diversos cónyuges simultáneos del causante, de nacionalidad marroquí, considerando compatible que el matrimonio celebrado por quien ya tenía un vínculo matrimonial previo se estime nulo en la legislación española y se deniegue su acceso al Registro Civil, con el hecho de considerar beneficiaria de la pensión de viudedad a la segunda esposa simultánea.

53. A destacar el caso de nacionales de Senegal, Gambia y Marruecos, reflejado en la STSJ de Andalucía de 30 de enero de 2003. 
de manera proporcional en función del tiempo de convivencia con el causante ${ }^{54}$. Pero nunca se otorga una pensión de viudedad completa a cada beneficiaria, pues ello supondría un enriquecimiento injusto de las mismas y perjuicio para la Seguridad Social.

Lo anterior permite concluir que cuando los solicitantes no son de países que tengan firmados convenios internacionales en materia de Seguridad Social que reconozca expresamente la pensión de viudedad en caso de poligamia, no existe una posición definida a la hora de resolver esta cuestión, resultando imprescindible que sea regulada por el legislador o interpretada por el Tribunal Supremo. Mientras que en el caso de que los cónyuges sean marroquíes o tunecinos y se haya contraído los matrimonios simultáneos en sus países de origen, corresponde aplicar los convenios sobre Seguridad Social que España tiene suscrito con tales países, y por tanto, sí se concede la pensión de viudedad. Precisamente el Instituto Nacional Seguridad Social ha sostenido esa postura, como regla general, otorgando la pensión a este tipo de ciudadanos, y aplicando generalmente las reglas de reparto del convenio, si bien no de manera unánime esto último.

Otro paso lo dan las SSTS de 24 enero de 2018 (recurso n. 98/2017) y de 17 de diciembre de 2019 (recurso n. 2679/2017), ambas de la Sala de lo Contencioso-Administrativo. En esta ocasión el tribunal admite, por primera vez, el derecho de una segunda viuda a cobrar la pensión de su cónyuge polígamo, de nacionalidad marroquí, y a repartírsela a partes iguales con la primera esposa, aplicando la regla de reparto establecida en el artículo 23 del convenio hispano-marroquí 55 .

La sentencia parte de que los matrimonios polígamos celebrados en el extranjero no resultan válidos en España en aplicación del orden público internacional español, pero como el uso del orden para restringir la norma de conflicto es una excepción al normal funcionamiento de la misma, esta excepción debe operar de modo restrictivo, lo cual supone que solo ha de operar cuando sea estrictamente necesario y en la medida en que sea preciso para proteger la estructura organizativa jurídica, moral y económica de la sociedad española. Por tanto la excepción (el orden público internacional) no debe fagocitar a la regla general (la norma de conflicto), debiendo actuar la primera solo con el fin de proteger los valores esenciales del Derecho español y solo en la medida estrictamente necesaria para evitar un perjuicio a los mismos ${ }^{56}$.

Sin embargo, pese a todo, en esta sentencia el causante estaba encuadrado en el régimen de clases pasivas al ser un funcionario al que se le aplicaba el régimen vigente hasta el 31 de diciembre de 2010. Y a causa de esto no le resultaba aplicable este convenio, el cual abarca las prestaciones del régimen general y determinados regímenes específicos. Pese a ello, el tribunal aplicó mediante "analogía juris" la tesis

54. En este sentido, la STSJ de Galicia de 2 de abril de 2002 y la STSJ de Madrid de 29 de julio de 2002.

55. Un comentario crítico de ambas sentencias en Sánchez-Rodas Navarro, C.: "Sinopsis del Convenio Hispano-Marroquí de Seguridad Social: desempleo, no contributivas, viudedad y poligamia". e-Revista Internacional de la Protección Social, vol. VI, núm. 1, 2021, pp. 4-11. También véase López Terrada, E. y Martín-Pozuelo López, Á.: "Los efectos del matrimonio poligámico en España: la pensión de viudedad", en AA.W.: Protección a la familia y Seguridad Social. Hacia un nuevo modelo de protección sociolaboral (tomo II), Laborum, Murcia, 2018, pp. 297 y ss.

56. Saad Bentaouet, M., "El convenio bilateral hispano-marroquí de seguridad social y su aplicación”, ob. cit., pp. 91-107. 
del orden público internacional atenuado aplicable al convenio, y por ende, estableció que se ha de recurrir al orden público internacional atenuado inclusive cuando no resulte procedente aplicar el convenio, en la búsqueda de un resultado justo. Por tanto, se admite el derecho de la segunda esposa a percibir la mitad de dicha pensión de viudedad, aplicando también la regla de reparto del convenio, sin aceptar la validez del matrimonio en España, puesto que solo se acepta un efecto colateral o periférico del mismo ${ }^{57}$.

\section{PENSIÓN DE VIUDEDAD EN EL SUPUESTO DE UNIÓN POR EL RITO GITANO}

La unión por el rito gitano y sus efectos en lo relativo a la pensión de viudedad ha sido, y sigue siendo, una cuestión controvertida y que no obtiene hasta el momento una solución, ni desde el punto de vista legal ni jurisprudencial.

La STC 69/2007, de 16 de abril, relativa al acceso a la pensión de viudedad del cónyuge superviviente de un matrimonio celebrado por el rito gitano. El Tribunal denegó la pensión, negando que se produjera cualquier tipo de discriminación, ya que este rito no es reconocido por el legislador como una forma válida de contraer matrimonio y las partes podían haberlo contraído libremente en alguna de las formas admitidas en Derecho. Sin embargo, posteriormente el Tribunal Europeo de Derechos Humanos contradijo al Tribunal Constitucional al reconocer la pensión de viudedad a la recurrente (aunque no plenos efectos civiles al matrimonio), considerando que la denegación de tal derecho suponía una diferencia de trato injustificada y desproporcionada frente a otras situaciones en las que se había extendido el derecho a quienes incumplían algún requisito de validez del matrimonio. Así lo manifestó en su sentencia de 8 de diciembre de 2009, asunto Muñoz Díaz c. España58.

Recientemente, con la STS de 25 de enero de 2018, n. 58/201859, otra vez se vuelve sobre esta cuestión controvertida. El tribunal deniega la pensión de viudedad a la mujer que había contraído unión conforme al rito gitano ${ }^{60}$.

Ahora, en 2021, se ha resuelto el recurso de amparo planteado, con lo que vuelve a estar en la palestra este problema no resuelto. La STC 1/2021, de 25 de enero ${ }^{61}$, ha declarado que a la recurrente en amparo no se le ha vulnerado su derecho a no ser discriminada por razón de raza/etnia reconocido en el artículo 14 CE al negarle una pensión de viudedad porque "la unión celebrada conforme a los usos y costumbres

57. Valverde Martínez, M. J. y Carrascosa González, J.: "Poligamia en Marruecos y pensión de viudedad en España. El Tribunal Supremo y el orden público internacional atenuado", ob. cit., pp. 718-731.

58. Véase Poquet Catalá, R.: "Pensión de viudedad y matrimonio contraído por el rito gitano", Nueva Revista Española de Derecho del Trabajo, núm. 243, 2021, pp. 287-314 y Blázquez Agudo, E. M.: "La denegación del matrimonio por el rito gitano como elemento de acceso a la pensión de viudedad: ni como matrimonio, ni como pareja de hecho", Estudios financieros. Revista de trabajo y seguridad social, núm. 422, 2018, pp. 158-163.

59. Ponente L. F. de Castro Fernández.

60. Quintanilla Navarro, R. Y.: "Pensión de viudedad en caso de unión por el rito gitano", en AA.W.: Protección a la familia y Seguridad Social. Hacia un nuevo modelo de protección sociolaboral (tomo II), Laborum, Murcia, 2018, pp. $385-392$.

61. Ponente E. Roca Trías. 
gitanos no ha sido reconocida por el legislador como una de las formas válidas para contraer matrimonio con efectos de validez civil". En consecuencia, no existe una discriminación directa basada en motivos sociales o étnicos al no haber equiparado la unión de la demandante con las uniones de hecho debida y legalmente formalizadas. Una señal más de lo controvertida que es esta materia lo constituye que el hecho de que la sentencia tiene un voto particular del magistrado Xiol Ríos ${ }^{62}$.

Como venía siendo habitual, también en esta ocasión se ha acudido ante el Tribunal de Estrasburgo a la vista del fallo que deniega la pensión de viudedad a la mujer viuda gitana63. Los argumentos del recurso ante el Tribunal Europeo de Derechos Humanos son los mismos que en el caso de la señora Muñoz. Hay una discriminación indirecta. Se aplica de forma ciega un requisito legal sin tener presente las circunstancias personales de esta mujer gitana. Se argumenta que se trata de una "discriminación intersectorial", pues entra en juego su origen étnico gitano, también la condición de mujer y rol de los cuidados; y la situación de vulnerabilidad socioeconómica64.

Se trata de un litigio, desde la perspectiva doctrinal, muy interesante ya que está en juego la existencia, por una parte, de una posible discriminación racial (contra la población gitana) y también de una posible discriminación indirecta por afectar especialmente a dicha población. El Tribunal Constitucional (tanto en 2007 como en 2021) ha perdido la oportunidad de analizar el litigio desde la perspectiva de una posible discriminación múltiple o interseccional por razón conjunta de raza y género.

Estas situaciones ponen de manifiesto que es precisa una revisión de la normativa reguladora de la pensión de viudedad acorde con los estándares fijados por el Tribunal Europeo de Derechos Humanos.

\section{REFLEXIÓN FINAL}

La pensión de viudedad ha ido evolucionando desde sus orígenes hasta la actualidad, fruto de la transformación social experimentada durante los siglos XX y XXI, debido a la absoluta integración de la mujer al mercado laboral, la normalización del divorcio

62. El voto particular del magistrado Xiol considera que existe una discriminación indirecta por razón de pertenencia a una minoría nacional en el trato dispensado para denegar la prestación por viudedad a las uniones de vida celebradas conforme a las tradiciones culturales del pueblo romaní que no sean inscritas en los registros específicos. El magistrado, en aplicación de la jurisprudencia constitucional, del Tribunal Europeo de Derechos Humanos y del Tribunal de Justicia de la Unión Europea, argumenta, con una amplia exposición de datos estadísticos, que la denegación de una pensión de viudedad en estas circunstancias implica una desventaja particular de los miembros de la comunidad romaní en relación con el resto de personas que conviven bajo la fórmula de uniones de vida registradas; y que la exigencia de inscripción de las uniones de vida para lucrar la prestación de viudedad cumple una finalidad de garantía que queda satisfecha, incluso en mayor medida, por los elementos que comporta la tradición cultural de la unión de vida celebrada conforme al rito romaní. Asimismo, resalta que no cabe excluir la concurrencia de la buena fe de la demandante de amparo como elemento relevante del juicio de proporcionalidad de la posible lesión del principio de no discriminación ponderado en la jurisprudencia establecida en la STEDH de 8 de diciembre de 2009, asunto Muñoz Díaz c. España.

63. Véase noticia publicada en https://www.europapress.es/sociedad/noticia-mujer-gitana-demanda-espana-tribunal-estrasburgo-denegarle-pension-viudedad-20210802235929.html.

64. Un comentario en Rodríguez Bravo de Laguna, J. J.: "Unión por el rito gitano y pensión de viudedad. A propósito de la sentencia del Tribunal Constitucional 1/2021, de 25 de enero", Revista de Derecho Social, núm. 93, 2021, pp. 133-142. 
dentro de la sociedad y la aparición de modos de convivencia alternativos al matrimonio, como es la pareja de hecho. Todo ello ha dado lugar a nuevos escenarios que reconocen como beneficiarios de la pensión a ciertas personas antes no protegidas. También se ha ido transformando la finalidad de la pensión, pasando de ser una pensión que cubría exclusivamente el estado de necesidad en el que se encontraba la viuda desvalida de primera mitad de siglo XX, a ser una pensión compensatoria que pretende resarcir el perjuicio que ha causado la pérdida del cónyuge o pareja.

La reforma llevada a cabo por la Ley 40/2007 reorienta parcialmente la finalidad de la pensión de viudedad, asociándola a la dependencia económica del superviviente respecto al fallecido, tanto al exigir determinados requisitos económicos a las parejas de hecho como al vincular el acceso de la pensión de viudedad de los excónyuges a la obtención de una pensión compensatoria. Si bien, este nuevo requisito dificulta el acceso a esta pensión por parte de los divorciados, la jurisprudencia ha tendido a flexibilizar tal requisito, ampliando el acceso a la misma a aquellos que disfruten de una pensión cuya finalidad sea similar a la compensatoria, pese a que las partes no la denominen como tal.

La Ley 40/2007 extendió la pensión de viudedad a las parejas de hecho, pero de manera limitada al condicionarlo al cumplimiento de una serie de requisitos simultáneos, conforme al Tribunal Supremo. Si bien, dentro de tales requisitos, la demostración de la convivencia estable y notoria durante los últimos 5 años puede ser tanto mediante certificado de empadronamiento como a través de otro medio de prueba fehaciente que lo corrobore, siguiendo así un criterio flexible. Por el contrario, la acreditación formal de la existencia de la pareja de hecho solo puede hacerse a través de la inscripción en el registro correspondiente o la constitución como tal ante documento público con una antelación mínima de 2 años. De esta manera se prioriza la acreditación formal de la pareja frente a la verdadera relación afectiva y estable que subyace entre los miembros, pudiendo dar lugar a situaciones un tanto injustas, resultando así de gran importancia conocer estas exigencias.

Precisamente como las nuevas realidades imponen nuevos escenarios que han de ser amparados por el Derecho, la proliferación de matrimonios polígamos contraídos en el extranjero y que viven en España, a consecuencia de la globalización y los fuertes flujos migratorios entre España y determinados países musulmanes, ha provocado estos últimos años la obligación de tener que determinar si este tipo de matrimonios puede acceder a la pensión de viudedad. En este sentido, tras varios años de múltiples sentencias contrapuestas de los diversos Tribunales Superiores de Justicia, actualmente se sigue la doctrina asentada por el Tribunal Supremo. Según este, se concederá la pensión de viudedad, a partes iguales, a todas las esposas simultáneas del fallecido, siempre que este sea nacional de alguno de los países firmantes de los acuerdos sobre Seguridad Social con España (Marruecos y Túnez), en tanto así viene determinado en dichos acuerdos y en aplicación del orden público internacional atenuado por el que se permite a la poligamia, pese a estar prohibida en nuestro ordenamiento jurídico, producir unos determinados efectos periféricos 
con vistas a cubrir una situación merecedora de protección por parte de la pensión de viudedad.

Sin embargo, cuando el matrimonio polígamo se celebre entre sujetos de otro país distinto de los anteriores, no hay una doctrina clara, unánime y definitiva que conceda o deniegue la pensión en tal caso, lo que supone un atentado contra el principio de seguridad jurídica.

Además, la pensión de viudedad no solo se ve afectada por las transformaciones experimentadas por la estructura familiar, sino también está condicionada por las nuevas realidades sociales tan importantes como es la violencia de género. Una lacra social que afecta a todas las vertientes de la vida.

Son muchos los problemas que rodean a la pensión de viudedad. También son muy abundantes los pronunciamientos de nuestros Tribunales de Justicia, en todas las instancias, y no solo en el orden jurisdiccional social, pues la jurisdicción contencioso-administrativa tiene mucho que decir en este tema. Tampoco es un tema olvidado por la doctrina científica. Quizás será el momento de plantear una reforma integral de la pensión de viudedad.

Para finalizar se debe, una vez más, afirmar que la regulación de la pensión de viudedad adolece de todos los defectos, lagunas y contradicciones que siempre se dan cuando se utiliza un método de reforma de una institución jurídica como el que se ha utilizado al ir reformando esta pensión. Como dijo Bernardo Gonzalo González, allá por los años 90 del siglo pasado: "falta diseño y abunda la política menuda y el bricolaje". Sirva el recuerdo de estas palabras como mi reconocimiento a su valía profesional, in memoriam.

\section{Bibliografía}

Allueva Aznar, L. y Ginés i Fabrellas, A.: "La dependencia económica como requisito de acceso a la pensión de viudedad en supuestos de separación o divorcio", Indret: Revista para el Análisis del Derecho, núm. 1, 2015.

Asín Cabrera, M. A.: "La práctica judicial española ante la diversidad multicultural de las relaciones familiares", Anuario de la Inmigración en España 2014, 2015.

Ballester Pastor, I.: "La cónyuge supérstite tiene derecho a acrecer su pensión de viudedad si fallece la cónyuge histórica-divorciada, con quien compartía ésta", Revista de Jurisprudencia Laboral, núm. 6, 2021.

Ballester Pastor, I.: "La cuantía de la pensión de viudedad tras la Ley 40/2007, de 4 de diciembre: cambios puntuales y entrada en juego de las uniones de hecho", Tribuna Social, núm. 209, 2008.

Blasco Rasero, C.: "Aplicación del régimen matrimonial en la delimitación de los beneficiarios de la pensión de viudedad", Temas Laborales, núm. 121, 2013.

Blázquez Agudo, E. M.: "La denegación del matrimonio por el rito gitano como elemento de acceso a la pensión de viudedad: ni como matrimonio, ni como pareja de hecho", Estudios financieros. Revista de trabajo y seguridad social, núm. 422, 2018.

Blázquez Rodríguez, I.: "Matrimonio celebrado por el rito islámico. Certificado de capacidad matrimonial y derecho internacional privado", Cuadernos de Derecho Transnacional, vol. 7, núm. 2, 2015.

Casas Baamonde, M. E.: "La pensión de viudedad de las parejas de hecho y su legítima vinculación asistencial a situaciones de necesidad económica", Revista de Jurisprudencia Laboral, núm. 1, 2019. 
Cervilla Garzón, M. J.: El derecho a la pensión de viudedad en el contexto de la violencia de género, Bomarzo, Albacete, 2017.

Chamales, T. T.: Cuando hierve la sangre, Ediciones Orbis, Barcelona, 1985.

Chano Regaña, L.: "El derecho a pensión de viudedad del supérstite de una unión de hecho homosexual", Anuario de la Facultad de Derecho de la Universidad de Extremadura, núm. 31, 2014.

De Castro Mejuto, L. F.: "A propósito de la pensión de viudedad para las parejas de hecho", Anuario da Faculta de Dereito da Universida de A Coruña, núm. 12, 2008.

Desdentado Daroca, E.: La pensión de viudedad ante los nuevos retos del Derecho de familia, Bomarzo, Albacete, 2009.

Gala Durán, C.: "Una aproximación a la nueva regulación propuesta en el marco de la pensión de viudedad", IUSLabor, núm. 1, 2007.

García Valverde, M. D.: "Mujer musulmana en España. Especial consideración del derecho a la pensión de viudedad", Revista Española del Derecho del Trabajo, núm. 181, 2015.

García Valverde, M. D.: "Mujeres musulmanas en España. Poligamia y derecho a la pensión de viudedad", en Carballeira Debasa, A. M. y González Santos, M. T. (coords.): Islam: pasado, presente y futuro. ¿Hacia una sociedad intercultural?, Dykinson, Madrid, 2016.

Gutiérrez Pérez, M.: "La pensión de viudedad frente a las distintas realidades familiares y sociales: poligamia y violencia de género bajo el foco de los últimos pronunciamientos judiciales", Revista Española de Derecho del Trabajo, núm. 210, 2018.

López Rodríguez, J.: "El derecho a la pensión de viudedad de las víctimas de violencia de género en los supuestos de separación o divorcio", en AA.W.: Protección a la familia y Seguridad Social. Hacia un nuevo modelo de protección sociolaboral, Laborum, Murcia, 2018.

López Terrada, E. y Martín-Pozuelo López, Á.: "Los efectos del matrimonio poligámico en España: la pensión de viudedad", en AA.W.: Protección a la familia y Seguridad Social. Hacia un nuevo modelo de protección sociolaboral (tomo II), Laborum, Murcia, 2018.

Martínez Abascal, V. A.: "Las parejas de hecho y la pensión de viudedad en la Ley 40/2007, de 4 de diciembre: ¿una equiparación inviable?", Aranzadi Social, vol. 2, núm. 17, 2010.

Moliner Navarro, R.: "El derecho a la percepción de una pensión de viudedad para las uniones de hecho formalizadas en la Comunitat Valenciana después de la STC 110/2016, de 9 de junio", Derecho Civil Valenciano, núm. 20, 2016.

Molins García-Atance, J.: "La pensión de viudedad tras la Ley 40/2007, de medidas en materia de Seguridad Social", Aranzadi Social, vol. 1, núm. 6, 2008.

Peña García, M. V: "Las prestaciones específicas de seguridad social para la mujer víctima de violencia de género", en Barrios Baudor, G. L. y Rodríguez Iniesta, G. (dirs.): Derecho Vivo de la Seguridad Social, Laborum, Murcia, 2019.

Poquet Catalá, R.: "El acceso de las parejas de hecho a la pensión de viudedad: ¿Una realidad?", Temas Laborales, núm. 119, 2013.

Poquet Catalá, R.: "Pensión de viudedad y matrimonio contraído por el rito gitano", Nueva Revista Española de Derecho del Trabajo, núm. 243, 2021.

Quintanilla Navarro, R. Y.: "Pensión de viudedad en caso de unión por el rito gitano", en AA.W.: Protección a la familia y Seguridad Social. Hacia un nuevo modelo de protección sociolaboral (tomo II), Laborum, Murcia, 2018.

Rodríguez Bravo de Laguna, J. J.: "Unión por el rito gitano y pensión de viudedad. A propósito de la sentencia del Tribunal Constitucional 1/2021, de 25 de enero", Revista de Derecho Social, núm. 93, 2021.

Saad Bentaouet, M.: "El convenio bilateral hispano-marroquí de seguridad social y su aplicación", e-Revista Internacional de la Protección Social, vol. III, núm. 2, 2018.

Sánchez-Rodas Navarro, C.: "Sinopsis del Convenio Hispano-Marroquí de Seguridad Social: desempleo, no contributivas, viudedad y poligamia". e-Revista Internacional de la Protección Social, vol. VI, núm. 1, 2021. 
Ureña Martínez, M.: "Parejas de hecho y pensión de viudedad tras las últimas sentencias del tribunal constitucional", Derecho Privado y Constitución, núm. 29, 2015.

Valverde Martínez, M. J. y Carrascosa González, J.: "Poligamia en Marruecos y pensión de viudedad en España. El Tribunal Supremo y el orden público internacional atenuado", Cuadernos de Derecho Transnacional, vol. 10, núm. 2, 2018.

Vicente Palacio, M. A.: "Pensión de viudedad y el tipo de documento público válido para constituir la pareja de hecho", Revista de Jurisprudencia Laboral, núm. 4, 2019. 